\title{
Total and Partial Substitution of Dietary Fish Oil with Palm Oil to Juvenile Crayfish, Procambarus Llamasi
}

Claudia Carmona-Osalde*, Miguel Rodríguez-Serna, Héctor Hernández-Moreno and Arredondo-Figueroa JL

Universidad Autónoma Metropolitana Iztapalapa (UAM-I), División de Ciencias Biológicas y de la Salud, Departamento de Hidrobiología, Planta Experimental de Producción Acuícola. Av. San Rafael Atlixco 186, Col. Vicentina, Iztapalapa 09340 México

\begin{abstract}
A 12-week feeding study was carried out to establish the effect of partial or total substitution of fish oil by plant oil in experimental fed diets in crayfish juveniles (Procambarus llamasi). Three isonitrogenous (30\% crude protein) and isoenergetic $(15.1 \mathrm{~kJ} / \mathrm{g})$ practical diets were formulated with $100 \%$ fish oil (FO), $100 \%$ plant oil (PO), and $50 \%$ $\mathrm{FO}-50 \% \mathrm{PO}$. The crayfish were raised on plastic tanks without water exchange, constant aeration, PVC shelters, with an average water temperature of $26 \pm 1^{\circ} \mathrm{C}$. Uneaten food and fecal residues were siphoned out from the tank bottom each morning. Crayfish total body weight (BW) and total length (TL) was measured every two weeks. Results showed that the use of plant oil did not significantly modified $(p>0.05)$ growth performance, survival or maturity of experimental organisms. All diets were offered to apparent satiation twice a day. Fed was consumed showing good results in all performance growth parameters and maturity index. In conclusion the present study clearly supported the possibility of total or partial substitution of fish oil by plant oil for crayfish. Despite the absence of fish oil as attractant in the diet with $100 \% \mathrm{PO}$, its acceptance was as good as the one containing it. $P$. Ilamasi demonstrated the feasibility of using a vegetable oil as lipidic energy source, which allows lowering costs in the use of fish oil about $66 \%$
\end{abstract}

Keywords: Plant oil; Fatty acids; Procambarus; Crayfish

\section{Introduction}

Fish oil is becoming more expensive and less available fatty acids in commercial foods [1,2]. However, current price and supply is fluctuating and for this reasons it is necessary to find new alternatives to replace and diminishing their use in food aquaculture with the main objective of reduce costs without affecting the growth performance.

Some vegetable oils had demonstrated to be a good alternative to replace fish oil in practical diets for fishes. The research of vegetables oils that can cover the nutritional requirements in different species has been made mainly in salmonids [3-5]. However, in the case of crustaceans information is scarce and only exist an antecedent with mud crab megalopae Scylla serrata [6].

The use of plant oil and their inclusion in different percentages in experimental diets is an important matter due the following reasons. First, this oil occupies the second place in world production and it is predicted that its future production will exceed that of soya oil in the next 10 years [7]. Second, their cost is up to $70 \%$ cheaper that fish oil, and third, their content of plantitic acid is highest in contrast with other available commercial vegetable oils (32-38\%) [1]. Crayfish particular information related to the fatty acids requirements and variation is poor. Only some antecedents regarding the effect in early stages requirements indicated that are small, with a negative effect in their growth and survival directly related with increasing percentage of inclusion [8]. Some studies settled down fatty acid composition in some species like Orconectes rusticus [9], Procambarus clarkii [10] in which it is demonstrated that plantitic acid is found in the hepatopancreas. Also, was demonstrated a narrow relationship among lipids percentage in the diet and the gonadal maturation [11], and in the modulation of the content and quality of lipids of the egg [12]. If we consider that in vertebrates the saturated fatty acids are closely related with the formation of cholesterol [13], and other lipids [14], we suppose that its inclusion in the diet will improve or may equal the indexes of acting of the crayfish fed with fish oil.
The aim of the present study was to establish the effect of the inclusion of different percentages of plant oil in experimental diets to determine its effect on growth performance and maturation indexes in crayfish juveniles Procambarus llamasi to totally or partially replace fish oil from diets in this freshwater crustaceans.

\section{Materials and Methods}

\section{Experimental diets}

Three experimental diets containing 30\% crude protein and $12 \%$ crude lipid were formulated using the same basal ingredients except for the oil content in each diet. Fish meal was used as the main source of protein. The source of lipid diets composition was fish oil (FO) and plant oil (PO) in different percentage of inclusion. Diets were formulated considering the $3.6 \%$ of FO coming from fish meal as follows. Diet 1 (D1), contained 100\% FO; Diet 2 (D2), contained 50\% FO and 50\% PO and Diet 3 (D3), contained 100\% PO. Proximate analysis was done according to the standard methods A.O.A.C. (1990). Data is showed in Table 1 . The results of fatty acids analysis are showed in Table 2.

Dry ingredients were weighed and then mixed in a food mixer (kitchen aid KSM 150 PS) for 15 minutes. Corn starch was mixed with

*Corresponding author: Claudia Carmona-Osalde, Universidad Autónoma Metropolitana Iztapalapa (UAM-I), División de Ciencias Biológicas y de la Salud Departamento de Hidrobiología, Planta Experimental de Producción Acuícola. Av. San Rafael Atlixco 186, Col. Vicentina, Iztapalapa 09340 México, Tel: +52 555804 4740; E-mail:caoc@xanum.uam.mx

Received February 06, 2015; Accepted June 25, 2015; Published August 15, 2015

Citation: Carmona-Osalde C, Rodríguez-Serna $M$, Hernández-Moreno $H$ Arredondo-Figueroa JL (2015) Total and Partial Substitution of Dietary Fish Oil with Palm Oil to Juvenile Crayfish, Procambarus Llamasi. J Aquac Res Development 6 : 367. doi:10.4172/2155-9546.1000367

Copyright: (c) 2015 Carmona-Osalde C, et al. This is an open-access article distributed under the terms of the Creative Commons Attribution License, which permits unrestricted use, distribution, and reproduction in any medium, provided the original author and source are credited. 
Citation: Carmona-Osalde C, Rodríguez-Serna M, Hernández-Moreno H, Arredondo-Figueroa JL (2015) Total and Partial Substitution of Dietary Fish Oil with Palm Oil to Juvenile Crayfish, Procambarus Llamasi. J Aquac Res Development 6: 367. doi:10.4172/2155-9546.1000367

Page 2 of 6

\begin{tabular}{|c|c|c|c|}
\hline \multirow[b]{2}{*}{ Ingredients (\%) } & \multicolumn{3}{|c|}{ Diets } \\
\hline & $100 \%$ Fish oil & 50:50 (Fish:Plant) & $100 \%$ Plant oil \\
\hline Fish meal & 50 & 50 & 50 \\
\hline Fish oil $^{1}$ & 8 & 4 & 0 \\
\hline Plant oil ${ }^{2}$ & 0 & 4 & 8 \\
\hline Raw corn starch & 18 & 18 & 18 \\
\hline White dextrin & 0 & 0 & 0 \\
\hline Mineral premix ${ }^{3}$ & 3 & 3 & 3 \\
\hline Vitamin premix ${ }^{4}$ & 3 & 3 & 3 \\
\hline Carboxymethyl cellulose & 18 & 18 & 18 \\
\hline Relation P/E (mg P/kcal) & 84 & 83 & 83 \\
\hline Gross Energy $(\mathrm{kJ} / \mathrm{g})^{5}$ & 358 & 360 & 360 \\
\hline \multicolumn{4}{|l|}{ Nutrient content ( $\%$ wet weight) } \\
\hline Dry matter & 95.18 & 95.11 & 95.58 \\
\hline Moisture & 4.82 & 4.89 & 4.42 \\
\hline Crude protein (nitrogen $\times 6.25$ ) & 31.56 & 31.93 & 29.52 \\
\hline Lipid & 12.76 & 10.96 & 11.82 \\
\hline Ash & 14.03 & 13.92 & 12.60 \\
\hline Crude fiber & 0.29 & 0.20 & 0.16 \\
\hline $\mathrm{NFE}^{\star}$ & 36.54 & 41.09 & 41.47 \\
\hline
\end{tabular}

${ }^{*} \mathrm{NFE}=100-(\%$ moisture+\%protein+\%lipid+\%ash+\%fiber)

${ }^{1}$ Fish oil was bought in Pharmacia Paris

²Plant oil was bought in SAARKA Nutrición y Tecnología, S. A. de C.V.

${ }^{3} \mathrm{~g} / \mathrm{kg}: \mathrm{MgSO}_{4} \cdot 7 \mathrm{H}_{2} \mathrm{O}, 10.434 ; \mathrm{KCl}, 2.0 ; \mathrm{NaCl}, 2.4 ; \mathrm{FeSO}_{4} \cdot 7 \mathrm{H}_{2} \mathrm{O}, 1.0 ; \mathrm{ZnSO}_{4} \cdot 7 \mathrm{H}_{2} \mathrm{O}$ $0.22 ; \mathrm{CuSO}_{4} \cdot 5 \mathrm{H}_{2} \mathrm{O}, 0.0314 ; \mathrm{MnSO}_{4} \cdot \mathrm{H}_{2} \mathrm{O}, 0.0769 ; \mathrm{CoSO}_{4} \cdot 7 \mathrm{H}_{2} \mathrm{O}, 0.0236 ; \mathrm{CaIO}_{3}$ $0.0185 ; \mathrm{CrCl}_{3} \cdot 6 \mathrm{H}_{2} \mathrm{O}, 0.0051$ (SAARKA, Nutrición y Tecnología, S. A. de C.V.)

${ }^{4} \mathrm{~g} / \mathrm{kg}$ : thiamin, 2.5; riboflavin, 2.5; panthotenicacid, 5.0; niacin, 10.0; pyridoxine, 2.0; biotin, 0.3; folic acid, 0.75; cyanocobalamin, 0.005; myoinositol, 100; ascorbic acid, 50.0; choline, 200; a-tocopherolacetate, 20.1, para-aminobenzoic acid 2.5; menadione, 2.0; vitamin D3, 0.0125; vitamin A, 0.03 (SAARKA, Nutrición y Tecnología, S. A. de C.V.)

${ }^{5}$ Calculated using the factors: carbohydrate, 4.1; protein, 5.5 and lipids, $9.1 \mathrm{kcal} /$ Table 1: Ingredient and proximate composition of experimental diets ( $\mathrm{g} / 100 \mathrm{~g}$ dry/ diet.

\begin{tabular}{|l|c|c|c|}
\hline Fatty acid & \multicolumn{3}{|c|}{ Diets } \\
\hline $14: 0$ & $\mathbf{1 0 0} \%$ Fish oil & $\mathbf{5 0 : 5 0}$ (Fish:Plant) & $\mathbf{1 0 0 \%}$ Plant oil \\
\hline $16: 0$ & 6.4 & 3.7 & 1.6 \\
\hline $18: 0$ & 17.1 & 29.7 & 37.9 \\
\hline Total saturated ${ }^{1}$ & 3.4 & 4.2 & 4.2 \\
\hline $16: 1 n-7$ & 6.7 & 38.2 & 44.1 \\
\hline $18: 1 n-9$ & 12.4 & 3.5 & 1 \\
\hline $18: 1 n-7$ & 2.5 & 25.1 & 35.9 \\
\hline $20: 1 n-9$ & 5.4 & 1.8 & 0.6 \\
\hline $22: 1 n-11$ & 7.2 & 2.8 & 0.4 \\
\hline Total monounsaturated & 36 & 2.5 & 0.4 \\
\hline $18: 2 n-6$ & 6.3 & 36.4 & 38.5 \\
\hline $20: 4 n-6$ & 0.6 & 9.9 & 11.8 \\
\hline Total $n-6$ PUFA ${ }^{3}$ & 7.6 & 0.3 & 0.2 \\
\hline $18: 3 n-3$ & 1.3 & 10.7 & 12.1 \\
\hline $18: 4 n-3$ & 2.9 & 0.9 & 0.6 \\
\hline $20: 5 n-3$ & 9.2 & 1.4 & 0.2 \\
\hline $22: 5 n-3$ & 1.2 & 4.7 & 1.2 \\
\hline $22: 6 n-3$ & 12.6 & 0.7 & 0.3 \\
\hline Total $n-3$ PUFA $^{4}$ & 28.2 & 6.4 & 2.7 \\
\hline & & 14.6 & 5.1 \\
\hline
\end{tabular}

${ }^{1}$ Total includes: $15: 0$ and 20:0

${ }^{2}$ Total includes: $16: 1 n-9,20: 1 n-7,22: 1 n-9$ and $24: 1$

${ }^{3}$ Total includes: $18: 3 n-6,20: 2 n-6$ and 22:5n-6

${ }^{4}$ Total includes: $20: 3 n-3$ and $20: 4 n-$

Table 2: Fatty acid composition of crayfish experimental diets (\% of total fatty acids).

warm water in a separate container before added to the dry ingredients. Finally oils were added, mixing all ingredients for about twenty minutes until homogeneous dough was formed. Pellets were made using a meat grinder and a 2-mm die. After pelleting, the diets were dried using a forced air drying oven $\left(<40^{\circ} \mathrm{C}\right)$ to a moisture content of $90-100 \mathrm{~g} / \mathrm{kg}$ for 12 hours, placed after in polyethylene bags and stored at $-5^{\circ} \mathrm{C}$ until used.

\section{Animals and experimental conditions}

For this study, 56 juvenile crayfish (Procambarus llamasi) with an individual mean initial body weight of approximately $0.57 \mathrm{~g}$ and an average total length body size of approximately $29 \mathrm{~mm}$, were obtained from a consultancy (Consultoria Integral y Servicios Profesionales del Sureste SRL) in Yucatan, Mexico, all of the same age and from the same spawn. Upon arrival at the PExPA (Aquaculture Experimental Plant) UAM-Iztapalapa University in Mexico City, they were placed into three 600-L black fiberglass tanks to acclimatize them to temperature $\left(26^{\circ} \mathrm{C} \pm 1\right)$ and management (fed twice a day with shrimp food, Purina $35 \%$ protein $6 \%$ lipids) for two weeks.

Crayfish were then randomly distributed into nine rectangular plastic tanks $(0.51 \mathrm{~m} \mathrm{~L} \times 0.34 \mathrm{~m} \mathrm{~W} \times 0.20 \mathrm{H})$ at six organisms/tank in a static experimental system which included automatic heater SAH-200, individual PVC shelters per tank and constant aeration. The indoor tanks were subjected to a photoperiod regime of 12-h light: 12-h dark.

Throughout 12 week experimental trial, each diet was randomly assigned by triplicate group of crayfishes. The crayfishes were fed with small pieces of pelleted food to satiety twice a day between 09:30 to 10:30 and 16:30 to 17:30. Every morning and afternoon tanks were checked for moults and death animals to be recorded and removed.

In this experiment, the crayfish were cultured in a static system, but every 15 days, there was a total water exchange. Uneaten food and fecal residues were siphoned out from the tank bottom each morning. Total water exchange was made every 15 days. The measured physicochemical parameters were found among normal range and no negative effect were observed on growth and survival rate. Mean water temperature, $\mathrm{pH}$ and dissolved oxygen throughout the experiment were $26.5^{\circ} \mathrm{C}, 9.1 \mathrm{mg} / \mathrm{L}$ and $5.1 \mathrm{mg} / \mathrm{L}$ respectively. Mean total ammonia nitrogen was $0.570 \mathrm{mg} / \mathrm{L}$; nitrite was $0.482 \mathrm{mg} / \mathrm{L}$ and nitrate was 13.1 $\mathrm{mg} / \mathrm{L}$.

All experimental organisms were individually weighed and measured every 15 days to collect growth data. Dead animals were removed and recorded to estimate survival. The performance indexes established were:

Survival (\%)=100 (Initial Number-Final Number)/Total Number

Weight Gain $(\mathrm{g})=($ Final Weight-Initial Weight $)$

Weight Gain in percentage (\%)=100 (Final Weight-Initial Weight/ Initial Weight

Length Increase $(\%)=100$ ((Final Length-Initial Length)/Initial Length)

Specific Growth Rate (\%/day=100 ( $\log _{\mathrm{e}}$ Final Weight- $\log _{\mathrm{e}}$ Initial Weight)/Time)

Feed Intake $(\mathrm{g})=($ Feed supplied-Remaining Feed $)$

Feed Conversion Rate $=($ Feed Intake/Weight Gain $)$ 


\section{Maturation}

Once growth experimental time was finished, all animals per treatment were pooled into one plastic tank (D1, D2 and D3 tanks) for a month, waiting for matting and spawned females. Over this period of time no growth or mortality was taken into account because of the high density managed. In non spawned females ovarian development was determined at the end of the experiment by dissecting them and observing differences in oocyte color [15]. The gonadosomatic index (GI) was calculated according to Pawson et al. [16] as

$$
\mathrm{GI}=100[\mathrm{wG} /(\mathrm{wF}-\mathrm{wG})]
$$

where:

$\mathrm{wG}$, is gonad weight.

$\mathrm{wF}$, is wet weight of female.

The maturation Index (MI) was calculated as follow:

$\mathrm{MI}=(\mathrm{E} \times \mathrm{AG}) / \mathrm{N}$

where:

$\mathrm{E}$, is the number of stages ( 7 in this case)

$\mathrm{AG}$, is the number of animals in each stage

$\mathrm{N}$, is the simple size

\section{Fatty acid composition of fish and plant oil}

The fatty acid composition of fish and plant oil used in the formulation of the experimental diets was determined according to the using 17 edition of gas chromatography of the standard references.

\section{Statistical analysis}

Survival, growth and maturity results were compared using a oneway analysis of variance (ANOVA) with $95 \%$ significance level. The differences among means were determined using the Tukey Multiple Range test. Statistical analyses were done using the Statgraphics V. XV software and data were normalized using the arcsine function when necessary.

\section{Results}

\section{Dietary fatty acid composition}

The fatty acid composition of the fish and plant oil used in this study are shown in Table 2. Diet formulated with $100 \%$ FO, contained approximately $27 \%$ of total saturates, while PO $44 \%$. The predominantly of them was $\mathrm{C} 16$ in all diets. Oleic acid (18: 1n-9) represented the second most important fatty acid in all diets with values increasing from $12 \%$ in FO diets to $35 \%$ in PO. Total monounsaturated represented about $36 \%$ in all diets. Linoleic acid (18:2n-6) in FO diet (6.3\%) was half the value from PO diet (11.8\%). Fish oil contained in general more EPA (20:5n-3) and DHA (22:6n-3) than plant oil. arachidonic acid (20:4n6) showed very low values in all diets with an average of 0.3 and the highest one for FO.

\section{Growth performance}

There were no significant differences in initial total weight and total length juveniles crayfish at the beginning of the experiment $(0.56 \mathrm{~g}$ and $29 \mathrm{~mm}$ in average). Similarly, results in growth performance and feed utilization of the three diets were not significantly different $(P>0.05)$. The three treatments showed good performance meaning diets were well accepted and ingested by crayfishes. The total weight increased two fold every month and no significant differences between treatments were observed. The highest total weight gain was $3.67 \mathrm{~g}$ in D3 (Figure 1). Specific growth rate did not show significant differences between diets with the highest value of $1.76 \%$ day $^{-1}$ were achieved in D3. Feed conversion ratio (FCR) fluctuated among 1.11 and 1.38. Crayfish mortality was around $20 \%$ for all treatments, without significant differences, although survival was similar in all treatments, the best result was obtained in D1 (Table 1).

\section{Maturation results}

During one month experimental period of matting, when crayfishes were gather in one tank per treatment, three spawned females were recorded one per treatment. This fact reflected a good performance of experimental diets as no differences were found between them. Spawned female sizes varied from 48 to $55 \mathrm{~mm}$ of total length.

Maturation index (MI) results showed not differences between diets (Table 2). Low indexes showed females in first maturation states and according to previous results [15] no synchronism in female maturation process was observed. The gonadosomatic index (GI) results showed similar results that those for the MI (Table 3).

\section{Discussion}

According to the present results, it is possible to total or partially substitute fish oil by plant oil due no significant differences were observed during twelve week experimental period in growth performance, survival and feed utilization. Experimental diets were well accepted and consumed by crayfishes which reflected a good growth in all treatments overcoming growth results previously reported in the same species by Carmona Osalde et al. and Rodriguez-Serna et al. [17,15]. Feeding diets containing PO in 50 and $100 \%$ of added oil had similar growth which leads the possibility of eliminating FO from crayfish food. Considering that fish oil presented in the fishmeal was enough to cover any essential fatty acid requirement.

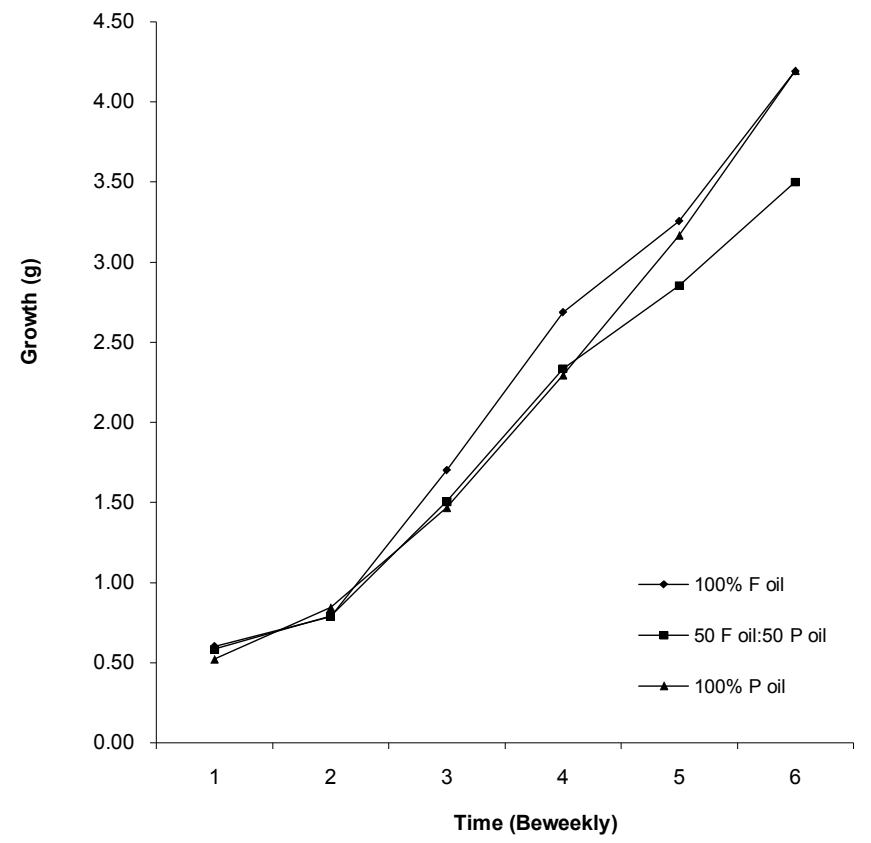

Figure 1: Mean $( \pm \mathrm{SE})$ growth of Procambarus llamasi over three months when fed diets with $100 \%$ fish oil, $50 \%$ fish oil and $50 \%$ palm oil, or $100 \%$ palm oil 
Citation: Carmona-Osalde C, Rodríguez-Serna M, Hernández-Moreno H, Arredondo-Figueroa JL (2015) Total and Partial Substitution of Dietary Fish Oil with Palm Oil to Juvenile Crayfish, Procambarus Llamasi. J Aquac Res Development 6: 367. doi:10.4172/2155-9546.1000367

Page 4 of 6

\begin{tabular}{|c|c|c|c|c|}
\hline & & Diets & & \\
\hline Parameter & $100 \%$ Fish oil & 50:50 (Fish:Plant) & $100 \%$ Plant oil & $\pm \mathrm{SE}$ \\
\hline Initial Weight (g) & $0.60^{\mathrm{a}}$ & $0.58^{a}$ & $0.52^{a}$ & 0.067 \\
\hline Final Weight (g) & $4.19^{a}$ & $3.50^{\mathrm{a}}$ & $4.19^{a}$ & 0.299 \\
\hline Survival (\%) & 83.3 & 72.2 & 72.2 & \\
\hline Weight gain $(g)$ & $3.56^{\mathrm{a}}$ & $2.86^{\mathrm{a}}$ & $3.67^{\mathrm{a}}$ & 0.348 \\
\hline Weight gain (\%) & $617.80^{a}$ & $537.60^{a}$ & $807.70^{a}$ & 126.9 \\
\hline Specific Growth Rate (\%/day) & $1.55^{\mathrm{a}}$ & $1.40^{\mathrm{a}}$ & $1.76^{\mathrm{a}}$ & 0.143 \\
\hline Individual Feed Consumed (g) & $3.93^{\mathrm{a}}$ & $3.53^{\mathrm{a}}$ & $3.82^{\mathrm{a}}$ & 0.327 \\
\hline Feed Conversion Ratio & $1.28^{\mathrm{a}}$ & $1.38^{\mathrm{a}}$ & $1.11^{\mathrm{a}}$ & 0.078 \\
\hline Initial Length (mm) & $30.16^{a}$ & $30.17^{a}$ & $29.50^{\mathrm{a}}$ & 0.982 \\
\hline Final Length (mm) & $53.02^{\mathrm{a}}$ & $50.86^{a}$ & $53.98^{a}$ & 0.949 \\
\hline Length gain $(\mathrm{mm})$ & $22.49^{a}$ & $19.56^{\mathrm{a}}$ & $22.15^{a}$ & 1.751 \\
\hline \multirow[t]{2}{*}{ Length gain (\%) } & $74.83^{\mathrm{a}}$ & $63.89^{a}$ & $84.39^{a}$ & 7.987 \\
\hline & & FEMALE & & \\
\hline Initial Weight (g) & $0.6^{\mathrm{a}}$ & $0.62^{\mathrm{a}}$ & $0.55^{\mathrm{a}}$ & 0.0757 \\
\hline Final Weight (g) & $3.9^{\mathrm{a}}$ & $3.5^{\mathrm{a}}$ & $3.9^{\mathrm{a}}$ & 0.596 \\
\hline Survival (\%) & 75 & 90 & 72 & \\
\hline Weight gain (g) & $3.31^{\mathrm{a}}$ & $2.85^{a}$ & $3.30^{\mathrm{a}}$ & 0.676 \\
\hline Weight gain (\%) & $589.5^{a}$ & $531.6^{a}$ & $687.6^{a}$ & 248.3 \\
\hline Specific Growth Rate (\%/day) & $1.54^{\mathrm{a}}$ & $1.44^{\mathrm{a}}$ & $1.54^{\mathrm{a}}$ & 0.262 \\
\hline Individual Feed Consumed (g) & $3.92^{\mathrm{a}}$ & $3.5^{\mathrm{a}}$ & $3.5^{\mathrm{a}}$ & 0.550 \\
\hline Feed Conversion Ratio & $1.23^{\mathrm{a}}$ & $1.28^{\mathrm{a}}$ & $1.20^{\mathrm{a}}$ & 0.187 \\
\hline Initial Length (mm) & $30.61^{\mathrm{a}}$ & $30.75^{\mathrm{a}}$ & $29.83^{a}$ & 0.958 \\
\hline Final Length (mm) & $52.3^{\mathrm{a}}$ & $51.1^{\mathrm{a}}$ & $52.3^{\mathrm{a}}$ & 1.753 \\
\hline Length gain (mm) & $21.4^{a}$ & $20.4^{a}$ & $22.1^{\mathrm{a}}$ & 2.537 \\
\hline Length gain (\%) & $69.9^{\mathrm{a}}$ & $68.3^{a}$ & $75.1^{\mathrm{a}}$ & 10.697 \\
\hline Gonad weight (g) & $0.06^{\mathrm{a}}$ & $0.06^{\mathrm{a}}$ & $0.07^{\mathrm{a}}$ & 0.006 \\
\hline Gonadosomatic Index (GSI) & $1.57^{\mathrm{a}}$ & $1.55^{\mathrm{a}}$ & $1.68^{a}$ & 0.057 \\
\hline Maturation Index (MI) & $1.97^{\mathrm{a}}$ & $1.68^{\mathrm{a}}$ & $1.96^{\mathrm{a}}$ & 0.061 \\
\hline Spawning rate $(\%)$ & $12.5^{\mathrm{a}}$ & $10^{\mathrm{a}}$ & $12.6^{a}$ & 0.577 \\
\hline
\end{tabular}

Numbers with the same superscript are not statistically different $(p>0.05)$

Table 3: Growth performance, feed utilization efficiency and biological index of crayfish $P$. llamasi using different inclusion percentage of plant oil.

Experimental organisms doubled their size every fifteen days reaching in three months a maximum average weight of $3.67 \mathrm{~g}$ and $53.98 \mathrm{~mm}$ in size. Percentage of weight gain fluctuated between 537 and $807 \%$, that represent eight fold increased than those results reported by Carmona Osalde et al. [15] with different protein/lipid ratios and [18] using shrimp commercial food.

No significant differences were found in survival, but best results were observed with D1. Mortality was due to aggressive encounters as result of growing and increasing size during moulting but no cannibalism was observed. This conduct was increased in the last weeks of the experimental period although food was given twice a day to apparent satiation.

Studies with marine crustaceans have reported better performance when diets contain fish oil compared to terrestrial sources as it is known they are incapable of de novo synthesizes of HUFA from linoleic and linolenic acids [19]. Larvae also seems to require high contents of n-3 HUFA for moulting in several species including Penaeus japonicas, Palaemon serratus, Macrobrachium rosenbergii, Homarus americanus and Carcinus maenas, although Holme et al. [6], found that diets for Scylla serrata megalopae may contain a ratio of 1:1 fish oil:corn oil with very good results. In this case, no negative effects were observed in crayfish performance, although fatty acid composition showed differences mainly in C16, EPA and DHA content.
No previous results are available on the substitution of fish oil in freshwater crustacean diets. But similar results are reported in shrimp Litopenaeus vannamei using different sources of oils [20]. In fishes, most of the work done is in rainbow trout Oncorhynchus mykiss [5] on the effect of temperature and fatty acid desaturation/elongation and $\beta$-oxidation. In Atlantic salmon (Salmo salar) no negative effects were observed in growth and feed efficiency in diets where fish oil was replaced by rapeseed [3] and with tilapia good results were obtain using plant oil in experimental diets in Oreochromis sp [1].

According to the available information on lipid metabolism in crustacean, particularly in the freshwater prawn Macrobrachium borellii transportation mechanism of plantitic acid is present in the hemolymph by High Density Lipoproteins (HDL) and between hemolymph and hepatopancreas. The study determined that more than $80 \%$ of the circulating plantitic acid was taken up by the hepatopancreas and incorporated into phospholipids (PC) and triacilgricerols (TAG). PC was the predominant circulating lipid and TAG was accumulated by the hepatopancreas. It may be inferred that the phospholipids synthesis in tissues is more active than that of neutral lipids [21]. Lavarías et al. [22] studied the capacity of energy generation through the activation and $\beta$-oxidation of plantitic acid in the midgut gland or hepatopancreas mitochondria in the same freshwater prawn, and found in the same species the presence of malonyl-CoA-sensitive 
carnitine O-plantitoyltranferase I, which in vertebrates controls the long-chain fatty acid synthesis and fatty acid oxidation and plays a major role in the control of mithocondrial $\beta$-oxidation flux. In these studies concluded that the presence of this enzyme may allow a high capacity for the midgut gland or hepatopancreas mitochondria to generate energy through $\beta$-oxidation. These may sustain our good results with plant oil as crustacean lipid metabolism is capable of using a saturated fatty acid (plantitic acid) as source of carbon for elongations of very long fatty acid and as energy source by $\beta$-oxidation.

Plantitic acid is a saturated long chain fatty acid with 16 carbon atoms (16:0) commonly find as a mainly lipidic component of crustacean hepatopancreas and hemolymph together with oleic and linoleic acids [23-26]. These fatty acids were the most abundant found in D3. In vertebrates, saturated fatty acids, especially plantitic acid, has important effects in cholesterol and lipoproteins metabolism [27] apparently acting in mRNA levels of genetic expression and cellular message control [28]. According to Van [14] when availability of plantitic acid increases in the cell it generates an accumulation in the intracellular membrane which promote the formation of phosphatidic acid, phospholipids and diacilglicerols.

The two experimental we reviewed all commercial vegetable oils. From all of them, plant oil was the only one containing the highest percentage of plantitic acid [29]. The two experimental diets were designed to partially or totally replace FO. We expected that the absence of FO in the diet will make it difficult for crayfish to develop, as the only source of FO was that from fish meal (3.6\%). But instead, crayfish performance in the diet with $\mathrm{PO}$ presented growth rates closed to FO diet, and result in females data were the same in almost all parameters. Maturation index was very similar to that reported by AOAC [30] where best result was 2.03 proving different protein/ lipid ratios. The number of spawned females found for each diet was the same (1/treatment) which showed no differences between diets. The differences in spawned rate reported were due to number of females presented in each treatment. Plant acid used may support very good growth and maturation which demonstrated very similar results as is other vertebrate organisms like fish.

In conclusion the present study clearly supported the possibility of total or partial substitution of fish oil by plant oil for crayfish without negative effects on growth and maturation performance. Despite the absence of fish oil as attractant in the diet with $100 \%$ PO, its acceptance was as good as the one containing it. Procambarus llamasi demonstrated the feasibility of using a vegetable oil as lipidic energy source which lower the cost of fish oil price about $66 \%$.

\section{References}

1. Bahurmiz OM, Ng WK (2007) Effects of dietary plant oil source on growth tissue fatty acid composition and nutrient digestibility of red hybrid tilapia Orochromis sp. raised from stocking to marketable size. Aquaculture 262: 382-392.

2. Tacon AGJ, Metian M (2008) Global overview on the use of fish meal and fish oil in industrially compounded aquafeeds: trends and future prospects. Aquaculture 285: 146-158.

3. Bell J G, McEvoy J, Tocher DR, McGhee F, Cambell PJ, Sargent JR (2001) Replacement of fish oil with rapeseed oil in diets of atlantic salmon (Salmo salar) affects tissue lipid composition and hepatocyte fatty acid metabolism $\mathrm{J}$ Nutr 131: 1535-1543.

4. Bransden MP, Carter CG, Nichols PD (2003) Replacement of fish oil with sunflower oil in feed for atlantic salmon (Salmo salar L.) effect on growth performance tissue fatty acid composition and disease resistance. Comp Bioch Physiol Part B 135: 611-625.

5. Tocher DR, Fonseca Madrigal J, Dick JR, Ng W, Bell JG (2004) Effect of wáter temperatura and diets containing plant oil on fatty acid desaturation and oxidation in hepatocytes and intestinal enterocytes of rainbow trout (Oncorhynchus mykiis). Comp Biochem Physiol Part B 137: 49-63.

6. Holme M, Southgate PC, Zeng C (2007) Survival development and growth response of mud crab Scylla serrata megalopae fed semi-purified diets containing various fish oil:corn oil ratio. Aquaculture 269: 427-435.

7. Ng WK (2006) Plant oil Malaysia's gift to the global aquafeed industry.

8. Ackefor H, Castell JD, Boston LD, Räty P, Svensson M (1992) Standard experimental diets for crustacean nutrition research II Growth and survival of juvenile crayfish Astacus astacus (Linné) fed diets containing various amounts of protein carbohydrate and lipid. Aquaculture 104: 341-356.

9. Wolfe DA, Venkata Rao P, Cornwell DG (1965) Studies on the fatty acid composition of crayfish lipids J Amer Oil Chem Soc 42: 633-637.

10. Okijama H, Ishii K, Watanabe $\mathrm{H}$ (1984) Studies on lipids of crayfish Procambarus clarkii I. Furanoid fatty acids Chem Pharm Bull 32: 3281-3286.

11. Carmona-Osalde C, Rodriguez-Serna M, Olvera-Novoa MA (2002) The influence of the absence of light on the onset of first maturity and egg laying in the crayfish Procambarus (Austrocambarus) Ilamasi (Villalobos, 1955). Aquaculture 212: 289-298.

12. Hdizic A, Hamadzic M, Gogic A, Majaljevic M, Vergara M, et al. (2008) The influence of dietary plant olein fish oil and lard on the egg yolk and plasma lipid composition and performance of laying hens Pol J Vet Sci 11: 1-7

13. Babin PJ, Gibbons GF (2009) The evolution of plasma cholesterol Direct utility or a sprandel of hepatic lipid metabolism? Prog Lip Research 48: 73-91.

14. Greevenbroek MM, Voorhout WF, Erkelens DD, Meer G, Bruin TW (1995) Plantitic acid and linoleic acid metabolism in Caco-2 cell different triglyceride synthesis and lipoprotein secretion. Journal of Lipid Research 36: 13-24

15. Carmona Osalde C, Rodríguez-Serna M, Olvera Novoa MA (2005) Effect of the protein-lipids ratio on growth and maturation of the crayfish Procambarus (Austrocambarus) llamasi. Aquaculture 250: 692-699.

16. Pawson MG, Pickett GD, Witthames PR (2000) The influence of temperature on the onset of first maturity in sea bass. Journal of Fish Biology 56: 319-327

17. Rodriguez-Serna M, Carmona-Osalde C, Olvera Novoa MA, Arredondo Figueroa JL (2000) Fecundity egg development and growth under two densities of juvenile crayfish Procambarus Ilamasi (Villalobos, 1955) under laboratory conditions. Aquaculture Research 31: 173-180

18. Kanazawa A (2001) Sterols in marine invertebrates. Fisheries Science 67: 997 1007

19. Bottino NR, Gennity J, Lilly ML, Simmons E, Finne G (1980) Seasonal and nutritional effects on the fatty acids of three species of shrimp Penaeus setiferus $P$ aztecus and $P$ duorarum. Aquaculture 19: 139-148.

20. González Félix ML, Lawrence AL, Gatlin III DM, Pérez Velazquez M (2002) Growth survival and fatty acid composition of juvenile Litopenaeus vannamei fed different oils in the presence and absence of phospholipids. Aquaculture 205: 325-343.

21. Garcia F, González Baro M, Pollero R (2002). Transfer of lipids between hemolymph and hepatopáncreas in the shrimp Macrobrachium borellii. Lipids 37: $581-585$

22. Lavarías S, Pollero RJ, Heras $H$ (2006). Activation of lipid catabolism by the water soluble fraction of petroleum in the crustacean Macrobrachium borellii. Aquatic Toxicol 77: 190-196.

23. Bragagnolo N, Rodriguez-Amaya DB (2001) Total lipid cholesterol and fatty acid of farmed freshwater prawn (Macrobrachium rosenbergii) and wild marine shrimp (Penaeus brasiliensis, Penaeus schmitti, Xiphpenaeus kroyeri). Journal of Food Composition and Analysis 14: 359-369.

24. Rodriguez Serna M, Carmona Osalde C, Arredondo Figueroa JL (2010) Growth of juvenile crayfish Procambarus llamasi (villalobos 1955) fed different farm and aquaculture commercial foods. Journal of Applied Aquaculture 22:1-9

25. Cabrera T, Cabrera G, Rosas J, Velásquez A, Silva M (2005) Variación de lípidos y ácidos grasos en camarones marinos consumidos en Venezuela Archivos Latinoamericanos de Nutrición 55: 194-200.

26. Biandolino F, Prato $E$ (2006) A preliminary investigation of the lipids and fatty acids composition of Gammarus aequicauda (Crustacea:Amphipoda) and its main food source. J Mar Biol Ass UK 86: 345-348. 
Citation: Carmona-Osalde C, Rodríguez-Serna M, Hernández-Moreno H, Arredondo-Figueroa JL (2015) Total and Partial Substitution of Dietary Fish Oil with Palm Oil to Juvenile Crayfish, Procambarus Llamasi. J Aquac Res Development 6: 367. doi:10.4172/2155-9546.1000367

Page 6 of 6

27. Kurushima H, Hayashi K, Shingu T, Kuga Y, Tanaka, et al. (1985) Opposite effects on cholesterol metabolism and their mechanism induced by dietary oleic and plantitic acid in hamsters. Bioch Bioph A 1258: 251-256.

28. Salter AM, Mangiapane EH, Bennett AJ, Bruce JS, Billett Ma et al. (1998) The effect of different dietary fatty acids on lipoprotein metabolism concentration: dependent effect of diets enriched in oleic myristic plantitic and stearic acids. Brit J Nut 79: 195-202.

29. Zar JH (1984) Biostatistical Analysis. Prentice Hall Inc., New Jersey.

30. AOAC (1990) Official Methods of Analysis of the Association of Official Analytical Chemists (15thedn.) AOAC Arlington VA 1141 